\title{
ROLE OF THE INTELLIGENCE IN THE SMALL AND MEDIUM-SIZE
} ENTERPRISES

\section{AZ INTELLIGENCIA SZEREPE A KIS- ÉS KÖZÉPVÁLLALKOZÁSOK VEZETÖINEK A MUNKÁJÁBAN}

Éva Fenyvesi, PhD, college professor

Budapest Business School, Faculty of Commerce, Catering and Tourism

Department of Economics

Address: $\quad$ 1054, Budapest, Alkotmány u. 9-11.

Phone: $\quad+36-30 / 921-1183$

E-mail: $\quad$ dr.fenyvesi.eva@kvifk.bgf.hu

Judit Vágány, PhD, college professor

Budapest College of Management

Department of Business Management

Address: $\quad 1114$ Budapest, Villányi u. 11-13.

Phone: +36-1-381-8114

E-mail: $\quad$ vagany.judit@avf.hu

Judit Daróczi Kárpátiné, college senior lecturer

Budapest College of Management

Department of Business Management

Address: $\quad 1114$ Budapest, Villányi u. 11-13.

Phone: +36-1-381-8114

e-mail: $\quad$ daroczi.judit@avf.hu 


\title{
AZ INTELLIGENCIA SZEREPE A KIS- ÉS KÖZÉPVÁLLALKOZÁSOK VEZETŐINEK A MUNKÁJÁBAN \\ ROLE OF THE INTELLIGENCE IN THE SMALL AND MEDIUM-SIZE ENTERPRISES
}

Key words: Small and medium-size enterprises (SMEs), Intelligence quotient (IQ), Emotional intelligence (EQ), Leaders' capabilities, Influence, Trust, Communication, Cooperation, Labour's recruitment

\begin{abstract}
The development of capabilities of managers' is determining factor in the future success of the economic enterprises. This diagnose is right especially in case of small and medium-size companies, as their focus has been moving towards more cost effective solutions due to limited resources. One of the solutions could be the improvement of human resources. The question is which capabilities of leaders can make the company be more effective. Intelligence tests are used for measuring managers' capabilities (results) in most cases. Opinion of professionals is split about which intelligence is more determining.

We have investigated two hypotheses in our research:

1 , There are more capabilities related to emotional intelligence for being more successful leader, for having more effective contribution in a team.

2, There are elements of EQ dominantly among the most important expectations for manpower.

We have got the following results after analyzing the 296 questionnaires

1, The EQ parameters (influencing, cooperation, communication, trust, relationship) have important role in their job by opinion of those leaders who have taken part in our research.

Influencing: leaders consider (72\%) the mentality of direct reports should be close to theirs as they can more easily influence them this way.

Cooperation: leaders have the feeling that they are really cooperative in sharing information, resources and ideas.

Relationship: $90 \%$ of those who sent back the questionnaire replied that they have good or excellent relationship with their colleagues. This has a major role in developing the cooperation and sharing information in the organization.

Communication: managers of small and medium size enterprises use frequently (95\%) the informal communication for solving professional problems. Female leaders feel their communication to be more effective than male leaders do $(74 \% ; 24 \%)$.

Trust: replies regarding to importance of trust among associates indicates that both genders consider it very important $(91 \%)$, however there were a few male leaders $(7 \%)$ whose opinion was that trust has no role in professional discussions.

2, There are elements of EQ dominantly among the most important expectations for manpower: leaders consider them important part in recruitment of new employee, however these elements are less preferred in the final decisions.
\end{abstract}

Kulcsszavak: kis- és középvállalkozások, intelligencia kvóciens (IQ), érzelmi intelligencia (EQ), vezetői képességek, befolyásolás, bizalom, kommunikáció, együttműködés, munkaerő kiválasztása

\section{Kivonat}

A gazdálkodó szervezetek jövőbeni sikerességét meghatározó tényező a vezetői képességek fejlesztése. Ez a megállapítás különösen igaz a kis- és középvállalkozásokra, hisz a forráshiány miatt a költségkímélőbb megoldások felé terelődik a hangsúly. Ilyen megoldás lehet például az emberi erőforrás jobb hasznosulása. A kérdés azonban az, hogy mik azok a vezetői képességek, amelyek hatékonyabbá tehetnek egy vállalkozást. A legtöbb esetben a vezetői teljesítmények vizsgálatát intelligencia tesztekkel végzik. A szakemberek véleménye azonban megoszlik abban a tekintetben, hogy melyik típusú intelligencia a meghatározóbb.

Kutatásunkban két feltevést vizsgáltunk meg:

1. Az eredményesebb vezetéshez, a csoportban való hatékonyabb munkához számos olyan képesség kötődik, ami az érzelmi intelligenciához kapcsolható.

2. A munkaerővel szembeni legfontosabb elvárások között dominánsan EQ elemek találhatók. 
A beérkezett kérdőívek (296 darab) adatainak feldolgozása után az alábbi eredmények születtek:

1. A vizsgálatban részt vett vezetők érzékelése alapján, az elemzett EQ tényezők (befolyásolás, együttműködés, kapcsolatépítés, kommunikáció, bizalom) fontos szerepet játszanak a munkájukban.

Befolyásolás. a vezetők fontosnak tartják (72\%), hogy a munkatársak mentalitása közel álljon saját mentalitásukhoz, ezen keresztül könnyebb az embereket a vezetőknek saját oldalukra állítani.

Együttmüködés. A vezetők úgy érzékelik, hogy az információk, erőforrások, tervek átadásában igen együttműködők.

Kapcsolatépités. A kérdőívet kitöltök 90\%-a úgy ítélte meg, hogy jó, illetve kitünő a kapcsolata munkatársaival. Ez nagyban segíti a kommunikáció, az együttmüködés létrejöttét a szervezetben.

Kommunikáció. A kis- és középvállalkozások vezetői gyakran (95\%) alkalmazzák a közvetlen kommunikációt a szakmai problémák rendezésére. A női vezetők azonban sikeresebbnek vélik kommunikációjukat, mint a férfivezetők $(72 \%$; 24\%).

Bizalom. A munkatársak közötti bizalom fontosságára vonatkozó eredmények azt mutatják, hogy mindkét nem igen lényegesnek tartja (91\%), a férfivezetők között azonban akadt néhány százalék (7\%), akik szerint szakmai kérdések megvitatásában a bizalomnak egyáltalán nincs szerepe.

2. A munkaerővel szembeni legfontosabb elvárások között szerepelnek EQ elemek: a vezetők a munkaerő kiválasztása során fontosnak tartják azokat, de választásuk során mégsem ezt preferálják.

\section{BEVEZETÉS}

\section{A KIS- ÉS KÖZÉPVÁLLALKOZÁSOK AKTUÁLIS HELYZETE}

A kis- és középvállalkozások (KKV) helyzete számottevő hatással van az egész gazdaságra Magyarországon és az EU-ban egyaránt. Arányuk a vállalkozásokon belül 99,9\%, illetve 99,8\%. A munkaerő foglalkoztatásban is oroszlánrész jut rájuk: $72,7 \%$, illetve $66,9 \%$. A nagyarányú hozzájárulás a foglalkoztatáshoz a hazai KKV-szektor nagy érdeme, és ez nemzetközi összehasonlításban is igaz. A szektor teljesítménye a hozzáadott érték tekintetében azonban 4,3\%-kal alatta marad az EU átlagnak. (1. táblázat)

A napjainkban tapasztalt turbulens környezeti változásokra a vállalkozások sokféle választ adhatnak, ilyenek többek között:

- a munkaerő leépítése,

- a K+F kiadások csökkentése,

- a marketingre fordított összegek visszafogása, stb. 
1. táblázat. A foglalkoztatás és a hozzáadott érték a különböző méretű vállalkozásokban Magyarországon és az EU-ban 2012-ben

\begin{tabular}{|c|c|c|c|c|c|c|}
\hline \multirow{2}{*}{ Vállalatméret } & \multicolumn{2}{|c|}{ Vállalatok száma } & \multicolumn{2}{c|}{ Foglalkoztatottak száma } & \multicolumn{2}{c|}{ Hozzáadott érték } \\
\cline { 2 - 7 } & Magyarország & EU27 & Magyarország & EU27 & Magyarország & EU27 \\
\hline Mikro & 94,8 & 92,2 & 36,4 & 29,8 & 18,2 & 21,2 \\
\hline Kis & 4,3 & 6,5 & 19,3 & 20,4 & 16,0 & 18,5 \\
\hline Közép & 0,7 & 1,1 & 16,9 & 16,8 & 19,6 & 18,4 \\
\hline KKV & 99,9 & 99,8 & 72,7 & 66,9 & 53,8 & 58,1 \\
\hline Nagy & 0,1 & 0,2 & 27,3 & 33,1 & 46,2 & 41,9 \\
\hline
\end{tabular}

Forrás: SBA Fact Sheet Hungary, 2012.

A vállalkozások e módszereket alkalmazzák leggyakrabban, s a legtöbb esetben fel sem vetődik annak lehetősége, hogy a kilábalás, sőt a fejlődés útja inkább az innovációs „elöremenekülés” pro - aktivitást jelentene. Azaz munkaerő leépítése helyett annak fejlesztését, képzését, a K+F kiadások, valamint a marketingköltségek csökkentése helyett, pedig más költségek lefaragását kellene megfontolni.

A témakörben megjelent tanulmányok is azt mutatják, hogy fejlesztés nélkül át lehet esetleg vészelni egy vállalkozás válságos időszakait, de a versenyképesség közép- és hosszú távú megőrzéséhez ez semmiképpen sem elégséges. A Boston Consulting Group (Rhodes Stalter, 2009.) kutatásai szerint azok a vállalkozások, melyek a gazdasági visszaesésre először habozva reagálnak, később általában túl súlyos intézkedéseket hoznak (nagyobb mértékben csökkentik a kiadásokat, mint amennyire végső soron szükség lenne). Ennek eredménye a legtöbb esetben az, hogy amikor újra beindul a gazdaság, a vállalatnak sokkal többe kerül a talpra állás, a „helyreállítás” költsége.

\section{A VÁLLALKOZÁSOK TELJESÍTMÉNYÉNEK NÖVELÉSE}

A legújabb tudományos és technológiai eredmények egyre nagyobb mértékben alakítják a versenyképesség feltételeit a KKV - szektorban is. A technológiai innováció erősödését számos tényező gátolhatja és segítheti. A legnagyobb korlát talán a forráshiány, ezért hangsúlyosan oda kell figyelni a költségkímélőbb megoldásokra, például a humántőke, ezen belül a menedzsment szerepére a meglévő emberi erőforrás kielégítő hasznosulása érdekében. A vállalat teljesítményét közvetlenül befolyásolják a menedzsment képességek (WimmerZoltayné 2006). A felkészültebb vezetők által irányított cégek hatékonyabban képesek 
reagálni a változásokra (pro - aktívabbak) és teljesítményük is jobb az átlagosnál. De vajon melyik vezető képes eredményesebbé tenni egy vállalkozást? A kutatások szerint a sikeres vállalatok vezetőinél különösen kiemelkedő a szakmai ismeret és a problémamegoldó képesség szerepe, de a kommunikációs képesség, az ötletek képviselete, a szervezési készség, a számítástechnikai ismeretek és az elemző készség terén is jobbak a lemaradóknál. A vezetői kompetenciák milyensége pedig kihat a dolgozók tudásának gyarapítására, az egész vállalat hatékonyságára. Ezen tényezők között szignifikáns kapcsolat fedezhető fel (Kárpátiné Vágány, 2011).

Azonban, nem könnyű rábírni egy szervezetet, hogy alkalmazkodjon a környezetében végbement változásokhoz. A vezetőknek gyakran szembe kell szállniuk a vállalati hagyományokat hủen követő gyakorlattal és tisztában kell lenniük azzal, hogy a megváltoztatásukra irányuló törekvések általában céltáblává tehetik őket (Kajári et al, 2007).Az „adaptív vezetésnek” nevezett gyakorlatot folytató vezetők a jelenben tapasztalható felfordulást arra használják, hogy lezárják a múltat. A folyamat során megváltoztatják az alapvető játékszabályokat, átalakítják a szervezet bizonyos részeit és újrafogalmazzák az alkalmazottak által elvégzendő munkát.

Ebből is látszik, hogy a vezetés legtöbbször improvizáló és kísérleti műfaj. Azok a képességek, melyek normál esetben a legtöbb menedzser számára lehetővé teszik, hogy irányító pozícióba kerüljenek - analitikus problémamegoldás, gyors és határozott döntéshozatal, egyértelmü irányvonalak kijelölése - időnként nem elégségesek a siker eléréséhez. Például, bizonytalan környezetben (válságban) nem tudható pontosan, hogy milyen irányban haladnak, amikor kialakítják a szervezet adaptivitását. Ilyenkor célszerü elkerülni a grandiózus részletekbe menő stratégiai terveket. Ehelyett sokkal inkább érdemes kísérletezni. Valószínüleg ezek közül számos sikertelennek bizonyul majd, és a cél felé vezető út állandó menet közbeni kiigazításból fog állni. Éppen ez a kitérőkkel tarkított útvonal játszik döntő szerepet abban a képességben, ami segíti a vállalatot a jobb termékek és eredményesebb folyamatok kialakításában (Heifetz - Grashow, 2009). Heifetz és munkatársa eredményeivel összecsengenek a Kotler és Caslione (2011) által megfogalmazott feladatok is. A vezetőknek tervezniük kell a „mának” és tervezniük kell a „holnapnak”, azaz „kettős víziót” kell kialakítaniuk, mely a rövid és a hosszú távú vízió együttesét foglalja magában. Eszerint a mára fókuszálva a jelenlegi ügyfelek igényeit figyelembe véve kell megfogalmazni a vállalat fő célját: a funkcionális tevékenységeiben megjelenő hatékonyság maximalizálását a jelenlegi lehetőségek tükrében. A holnapra fókuszálva pedig úgy kell kialakítani az üzleti vállalkozást, 
hogy az a jövőben hatékonyabban állja a versenyt (Kotler - Caslione, 2011). Tomka (2012) szerint a vállalatoknak tripla tervezésre (rövid, közép és hosszú távon) van szüksége, és ha a hosszú távú tervezés elmarad, ez azt jelenti, hogy a vállalat nem kedveli a kihívásokat.

De vajon mitől lesz eredményesebb az egyik vezető a másiknál? Milyen képességek, személyiség jegyek különböztetik meg őket, és ezek a vezetők milyen képességekre, személyiségjegyekre helyezik a hangsúlyt az új munkaerő kiválasztásnál?

Kutatásunkban feltételezzük, hogy

- az eredményesebb vezetéshez,

- a csoportban való hatékonyabb munkához számos olyan képesség kötődik, ami az érzelmi intelligenciához kapcsolható.

\section{AZ INTELLIGENCIA ÉS A MUNKATELJESÍTMÉNY ELŐREJELEZHETŐSÉGE}

Az IQ használhatóságáról szóló vitákban vannak olyan kutatók, akik az IQ mellett voksolnak (Carroll, 1993; Herrnstein - Murray, 1994; Hunter, 1983). Hunter például (1983) úgy véli, hogy az intelligencia tesztek ponteredményei a munkateljesítményt képesek előre jelezni számos oldalról. Ilyenek például a főnöki ítélet, a munkadarabok minősége. Más kutatók azonban nem tartják eléggé megalapozottnak az IQ általános alkalmazhatóságát (Gardner, 1983; Ceci, 1990; Neisser at all, 1996). Ez utóbbi vélemények közül az egyik szerint, ezek a tesztek csak kis részét - kevesebb, mint egynegyedét - igazolják a munkával összefüggő mérőszámok varianciájának. Az IQ tesztekkel nem mérhető személyiség vonásokat azonban legalább ilyen fontosak tartják (Neisser at all, 1996).

Ezen bírálatok hatásaként több új megközelítés látott napvilágot. Ilyen a gyakorlatban talán egyik legtöbbet alkalmazott „többszörös intelligencia” modell (Gardner, 1983). Gardner hét egymástól függetlenül létező intelligenciát azonosított: nyelvi (szóbeli), zenei, logikai, matematikai (absztrakt gondolkodás képessége), téri (téri vizuális információ észlelése), testi, kinetikus (mozgásos), személyes (intraperszonális), társas (interperszonális). 


\section{1. ábra. Az EQ négy komponense és a hozzájuk tartozó alskálák}

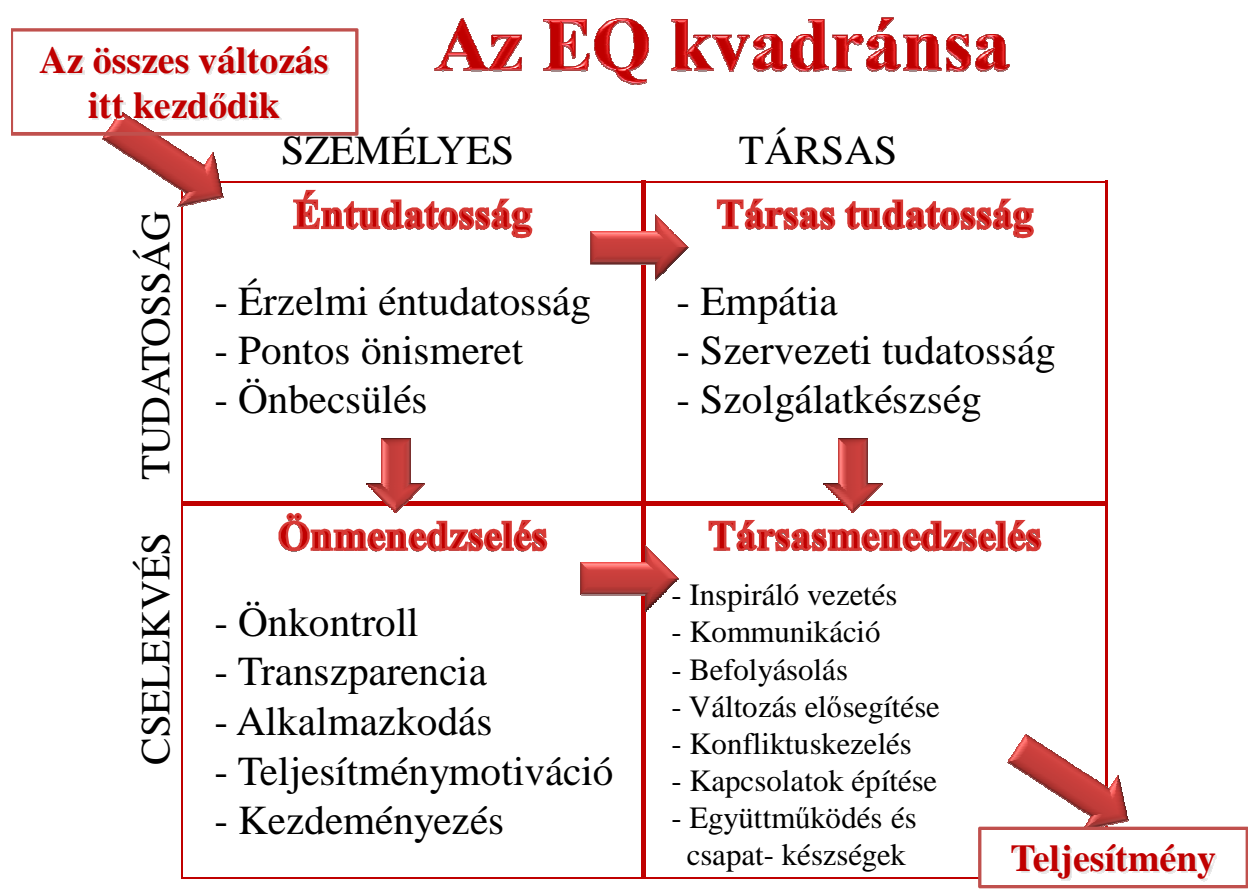

Forrás: (Boyatzis, Goleman és McKee (2003), saját szerkesztés

Mások az agykutatások legújabb eredményeire támaszkodva alkotottak új modellt (Solovey - Mayer, 1990; Goleman, 1997). Ilyen modell az érzelmi intelligencia (EQ). Bár az EQ Goleman (1997) által vált híressé, az alapokat Salovey és Mayer (1990) fektette le. Goleman később saját modelljét is módosította (Boyatzis at all, 2003). Így az eredeti öttényezős (érzelmek ismerete, az érzelmek kezelése, önmotiválás, mások érzelmeinek felismerése és az emberi kapcsolatok kezelése) EQ modellt a későbbiekben négy összetevővel (én - tudatosság, önmenedzselés, társas tudatosság és kapcsolatmenedzselés) írja le. A négy komponens alá 19 alskála tartozik (1. ábra), amelyek a munkateljesítményt is jelentősen meghatározó képességekből és személyiségjegyekből állnak. Az EQ modell elterjedése kapcsán több kutató szerint az emberiség IQ-ja elmúlt száz évben folyamatos növekedést mutatott, ezzel szemben érzelmi intelligenciája (EQ) csökkent (Fenyvesi, 2010).

Megint mások (Mérő, 2010) azt állítják, hogy az IQ és az EQ „valószínűleg” szorosan összefügg egymással, és élesen bírálja Goleman-t, aki szembe állítja azokat. Mérő szerint a „,speciális képességek jól fejleszthetőek, ha megvan az IQ szint, amely eleve szükséges hozzájuk” (Mérő, 2010: 187), azaz „EQ valójában az IQ egyik komponense... ...nem egy eddig feltérképezetlen kontinenst derített fel, hanem nagymértékben finomította a korábban sikerrel alkalmazott térképeinket, például az IQ-t” (Mérő, 2010). 
Egy dolog bizonyosnak látszik: a kutatók által EQ-hoz kapcsolt képességek, személyiségjegyek fejlettsége meghatározó a munka, illetve a vezetői hatékonyság területén. Dulewicz és Higgs (1998) 7 éven keresztül követte nyomon 58 vállalati vezető karrier előmenetelét Angliában és Írországban. A végső eredmények azt mutatták, hogy a vizsgált három elem közül az EQ valamivel erősebben járult hozzá az előmenetelhez (az EQ 35\% varianciát, az IQ 27\%-osat, míg a vezetői képességek 16\%-osat mutattak). Az Egon Zehnder International kutatócég 515 felsővezető esetében végzett vizsgálatot. Az eredmények szerint a sikeres vezetőknek 74\%-ban magas érzelmi intelligenciája volt, míg a kevésbé sikereseknél, ez az érték, csak 24\% volt. Egy szintén EQ kutatás szerint az USA légierejénél a sorozók kiválasztását EQ teszt alapján végezték, amely háromszorosára növelte a sikeres sorozók kiválasztását. Hasonló eredmények születtek a L'Oreal-nál is. Azok az üzletkötők, akiket bizonyos érzelmi kompetenciák alapján választottak ki, kimutathatóan többet adtak el, mint azok, akiket a cég régi kiválasztási módszerével vettek fel.(Cherniss, 1999).

Kutatásunkban mi nem arra fókuszáltunk, hogy eldöntsük az EQ önállóan vagy az IQ részeként van-e jelen, hanem arra, hogy bebizonyítsuk a csoportban való munkához számos olyan képesség szükséges, ami az érzelmi intelligenciához kapcsolható. Az együttműködéshez egy csoport tagjainak meg kell tanulniuk önmérsékletet mutatni, másokat meggyőzni, tapintatosnak és megértőnek lenni. Mindez pedig kellő érzelmi intelligencia szintet feltételez. E készségeknek a birtokában az egyén képessé válhat arra, hogy az együttmüködés, versengés közötti választást megfelelően kontrollálja, és ne csak saját, hanem a közösség érdekeit is felismerje. A fenti képességek hiányában nehezen teremthető olyan kapcsolat az egyének között, amely az együttmüködő, tudásmegosztó kultúrát támogatja.

Az így értelmezett EQ szerepe nemcsak az egyének, hanem a csoportok és a szervezetek életében is döntő fontosságú. Ha magas egy csoport érzelmi intelligenciája, lehetővé válik olyan harmonikus légkör kialakítása, amelynek jóvoltából mindenki tehetsége érvényre juthat. Az ilyen légkörben könnyebben kialakul a laza munkatársi hálózatokra való támaszkodás. Druskat és Wolf (2002) szerint a csoport eredményessége alapvetően három feltételtől függ: a bizalomtól, a csoportszellemtől (összetartozás), a csoport segítőerejének az érzésétől. Mindegyik feltétel elsősorban az érzelmekre vezethető vissza. Ezeknek növeléséhez szükséges normák származhatnak a formális és informális csoportok vezetőitől, a bátor követőktől, a képzések eredményeként és nem utolsó sorban a szervezeti kultúrából. A személyes bizalom és annak meghatározó tényezői, illetve az érzelmi intelligenciát alkotó 
személyes kompetenciák közötti kapcsolatra hívja fel a figyelmet Kovács (2010) is „A bizalom szerepe és helye az érzelmi intelligenciában" című munkájában.

\section{A KUTATÁS MÓDSZERTANA}

A kutatásunk célja volt egyrészt a KKV-k munkaerővel szembeni munkaerő-piaci elvárásainak feltárása, másrészt a vállalkozások minőségirányítási, minőségbiztosítási helyzetének megismerése, harmadrészt a KKV - vezetők EQ - érzékenységének vizsgálata volt.

A kutatáshoz megfogalmazott hipotéziseink:

- Az eredményesebb vezetéshez, a csoportban való hatékonyabb munkához számos olyan képesség kötődik, ami az érzelmi intelligenciához kötődik.

- A munkaerővel szembeni legfontosabb elvárások között dominánsan EQ elemek találhatók.

A kutatási kérdések megválaszolásához kvantitatív módszert alkalmaztunk: az adatgyüjtést kérdőíves felméréssel végeztük. A vállalkozásokról szóló kérdőíves vizsgálat 2012 februárjában kezdődött, és profitorientált, illetve nonprofit mikro-, kis- és középvállalkozásokra terjedt ki. Jelen tanulmányban ebből a munkaerő-piaci elvárások feltárására irányuló kutatás legfontosabb részeredményei kerülnek ismertetésre.

Kérdőívünk 1. változatát 2012 februárjában próbalekérdezéssel teszteltük, melybe az Általános Vállalkozási Főiskola hallgatóit, valamint 12 vállalkozást vontunk be. Az intézmények vezetőit/középvezetőit kérdezőbiztosok segítségével kerestük fel és kértük meg a vizsgálatban való részvételre. A kérdezőbiztosoknak 2012 februárjában előzetes felkészítést tartottunk, valamint részletes kitöltési útmutatót mellékeltünk számukra. A válaszadás önkéntes volt.

A felmérésben résztvevők két fő témakörben összesen 26 kérdéskörre válaszolhattak, melyek további segédkérdéseket is magukban foglaltak. A kérdőív két fő kérdésköre: az „Általános adatok” és „A vállalkozás működésével kapcsolatos kérdések” témakörök. Az „Általános adatok” témakörben a válaszadók demográfiai adataira - nem, beosztás - valamint az általuk képviselt intézmény székhelyére, alapításának évére, tevékenységi körére, a cég jogi formájára, alkalmazotti létszámára, éves árbevételére, valamint tulajdonosi szerkezetére kérdeztünk rá. „A vállalkozás müködésével kapcsolatos kérdések” témakörnél a szervezeti struktúrára, stratégiára és a vállalkozás vezetőinek „EQ érzékenységére” voltunk kíváncsiak, ezen kívül a vállalkozások vezetőinek az új munkaerővel szembeni elvárásait kérdeztük meg. 
A 2. számú táblázatban foglaljuk össze azokat a képességeket és személyiség jegyeket, amelyekre vonatkozóan a kérdőív vonatkozó részében felmérés készültt.

\section{2. táblázat. IQ és EQ jellemzők}

\section{IQ'-hoz kapcsolható $\quad \mathrm{EQ}^{2}$-hoz kapcsolható képességek és személyiség jegyek}

analitikus szemlélet elemzőkészség; nyelvtudás; számítógépes ismeret; szaktudás alkalmazása a gyakorlatban; probléma-megoldási készség; pontos, precíz munkavégzés; teljesítmény-, ill. eredmény-orientáltság; munkabírás, terhelhetőség; fejlődőképesség megbízhatóság; együttműködés; önfejlesztés, fejlődőképesség; kreativitás; kapcsolatépítés képessége; stressz-türő képesség; motiválási képesség; munka iránti alázat; kommunikációs képesség; önállóság; kezdeményező-készség; rugalmasság; szervezési készség

Saját szerkesztés

A válaszadóktól egyrészt eldöntendő, másrészt Likert - kálán történő értékelést kértünk, harmadrészt pedig kiegészítő szöveges megjegyzés/vélemény kifejtésére is lehetőséget adtunk.

Az 1. vizsgálati szakaszban összesen 354 kérdőív érkezett be. A válaszadási hajlandóság jónak mondható: a megkérdezett intézmények 84\%-a a kérdések több, mint 90\%-át megválaszolta. Az ellenőrzés során helytelen, vagy hiányos, vagy nem megfelelő személy (vezető) által történt kitöltés miatt 58 kérdőívet értékelhetetlennek minősítettünk, így összesen 296 értékelhető kérdőívet dolgoztunk fel.

A kérdőívek kódolása Excel 2007 programmal történt, az adatokat pedig SPSS 18 program segítségével elemeztuik. A statisztikai értékelés egyváltozós elemzésekkel (gyakoriság, módusz, variancia) és kétváltozós, kereszttábla-elemzéssel történt.

\footnotetext{
${ }^{1}$ „, Binet az értelmi képességeket több részképesség összességének tekintette, és ezeket a képességeket mérte. Az általa kidolgozott intelligenciateszt, illetve az eljárására épített IQ nagy karriert futott be”..., „Az azóta is alkalmazott eljárás az IQ (intelligencia quotiens) kiszámítására, hogy a tizedes - törtet, mint hányadost 100-zal megszorozzák, így létrejön az életkori kvóciens. Azaz ha egy nyolc éves gyerek a tíz évesek feladatait tökéletesen megcsinálja, akkor -minthogy értelmi kora 10 év, valódi kora pedig 8 - hányadosa 10/8x100, azaz 125 lesz." (Gyarmathy, 2002:130)

${ }^{2}$ „Az EQ az a merőszám, amely megmutatja, mekkora önismerettel bírunk, mennyire vagyunk képesek beleélni magunkat mások helyzetébe (empátia), szükség esetén háttérbe tudjuk-e szorítani saját érdekeinket másokéval szemben, eredményesen tudunk-e együttmüködni másokkal." (Zsoldos, 2009:108)
} 


\section{KUTATÁSI EREDMÉNYEK}

A mintába került vállalkozások alkalmazotti létszám szerinti megoszlása ${ }^{3}$ a következő: a mikro - vállalkozások több mint 70\%-os arányban szerepelnek a mintában, a kisvállalkozások a minta 17,1\%-át, a középvállalkozások a 9,8\%-át teszik ki (2. ábra). A KSH adataihoz viszonyítva a mikro - vállalkozások alul-, a kis- és középvállalatok pedig felülreprezentáltak (SBA Fact Sheet Hungary, 2012)

\section{2. ábra. A megkérdezettek megoszlása a vállalkozás mérete szerint}

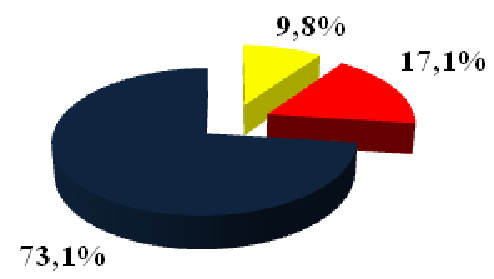

Középvállalat

- Kisvállalkozás

- Mikrovállalkozás
3. ábra. A megkérdezettek megoszlása cégforma szerint

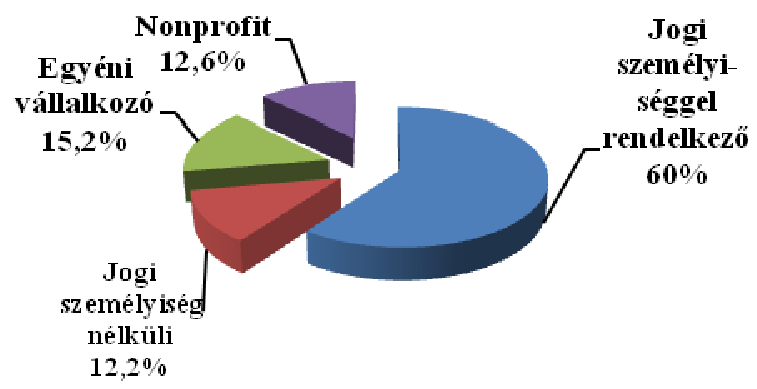

Forrás: saját szerkesztés

Forrás: saját szerkesztés

Cégformáját tekintve a megkérdezett vállalkozások több mint 60\%-a jogi személyiséggel rendelkező (kft, nyrt, zrt.), míg 12, 2\%-a jogi személyiség nélküli gazdasági társaság (bt, kkt.). Az egyéni vállalkozók 15,2\%-ban szerepeltek a mintában, a többiek pedig a nonprofit szférából kerültek ki. (3. ábra)

Kutatásunk egyik részeredménye a vezetők néhány olyan személyiség jegyét vizsgálta, amelyek az EQ kvadránsából a társas menedzselés komponenseihez (lásd 1. ábra) kapcsolhatók leginkább. Felmérésünkben e hét elem közül is csupán a befolyás, az együttmüködés, a kommunikáció és a kapcsolatépités megítélését mértük a vezetők mindennapi munkájában.

A vezetők feladata, olyan körülmények teremtése, amelyek között a munkatársakban levő motivációk felszabadulnak és megvalósítható célok irányába vezetődnek le. A befolyásolás olyan hatékony meggyőző képesség, amely azt támogatja, hogy másokat a saját oldalunkra állítsunk. Ennek a képességnek a birtokában lehetővé válik, hogy másokban szimpátiát, és hasonlóság érzetet, bizalmat keltsünk. Ha ez sikerül, nagy haszna lehet a munkatársak

\footnotetext{
${ }^{3}$ A KKV-k méretének meghatározásánál a kis- és középvállalkozásokról, fejlődésük támogatásáról szóló2004. évi XXXIV. tv. által definiált kategóriákat tekintjük alapnak, mely szerint a mikrovállalkozás 0-9 főt, a kisvállalkozás 10-49 föt, a középvállalkozás pedig 50-249 föt foglalkoztat.
} 
motiváltságának erősítésében. Hisz az embereket kívülről nem, vagy csak korlátozott mértékben lehet motiválni, erre elsősorban ők saját maguk képesek.

\section{4. ábra. Munkatársainak mentalitása mennyiben hasonló az Önéhez?}

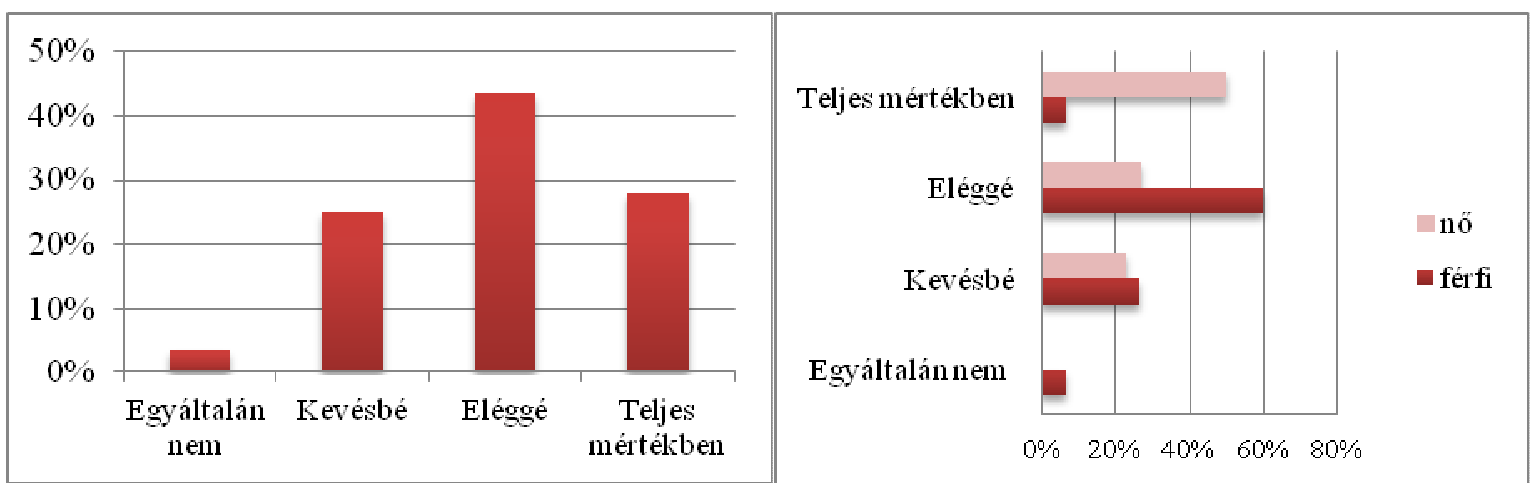

Saját szerkesztés

A válaszokból úgy tünik a vizsgálatban részt vevő vezetők számára fontos, hogy elsősorban olyan munkatársakkal vegyék körül magukat, akik mentalitása közelebb van a saját mentalitásukhoz. A hasonló beállítottságú embereket pedig nagyobb valószínűséggel sikerül a közös célok megvalósítása irányába „terelni”. Ez a női vezetőknél sokkal inkább a teljes egyezőség felé mozdul el, mint a férfiaknál (4. ábra).

\section{Kommunikáció}

Az emberek hatékonyságát nagyban befolyásolja a kommunikációs készségük. A kommunikáció hatékonyságát elemző kutatások szerint azoknak a személyeknek kb. 80 százaléka, akik munkájukat kudarcként élik meg, ezt egyetlen okból teszik: nem jól viszonyulnak másokhoz. Ez a képesség segít a kölcsönös megértésben, a problémás helyzetek könnyebb megoldásában. A számítógépes rendszerek ugyan jelentősen megkönnyítik az adatok, információk átláthatóságot, azonban nem helyettesítik a közvetlen beszélgetést. Az adatbázisok és egyéb informatikai és papíros alapú tárolók képesek rengeteg adat és információ tárolására, de a fejekben lakozó tudás hozzáférhetőségét a tagok közötti kétirányú kommunikáció biztosítja. Ahhoz, hogy kicseréljék gondolataikat és érzéseiket, interakcióba kell lépniük egymással.

\section{5. ábra. Problémás helyzetekben, mennyiben sikerül a problémát megoldania kommunikáció útján?}




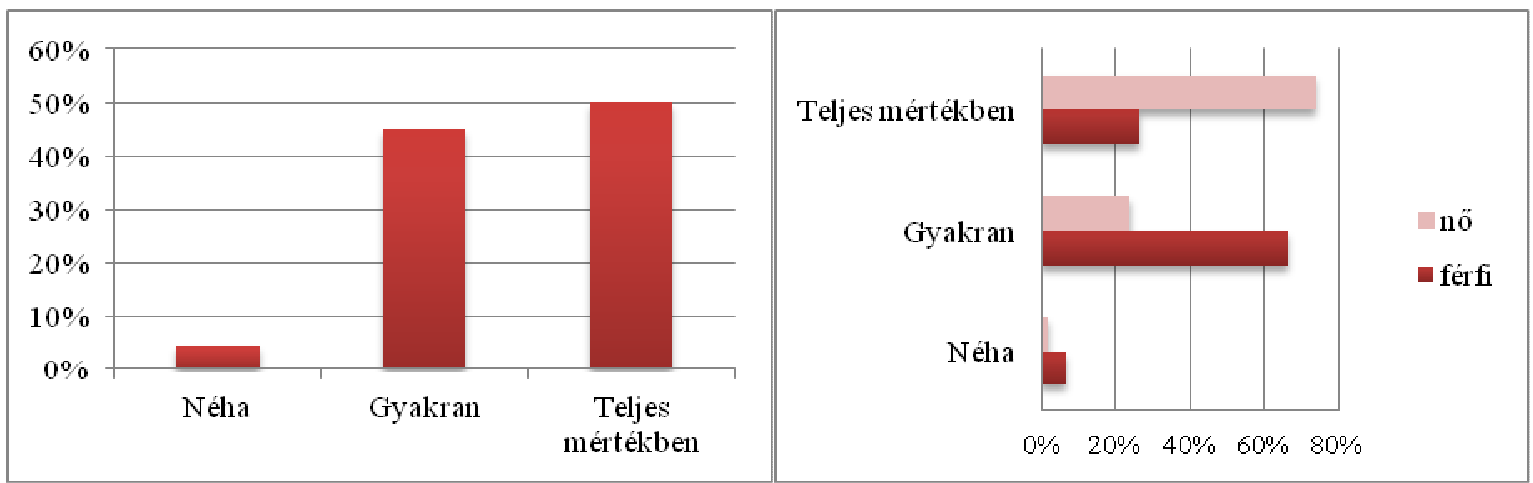

Saját szerkesztés

A vizsgálat eredményei is azt mutatják, hogy a problémamegoldás gyakori eszközének tartják a vezetők, a közvetlen kommunikációt. A felmérés szerint a női vezetők sikeresebbnek érzik saját kommunikációjukat, mint a férfiak. E mögött az is meghúzódhat, hogy a nők könnyebben érzékelik és kiértékelik a metakommunikáció jeleit (a kommunikációnak mintegy 70-80 \%-a zajlik ezen a non-verbális csatornán) (5. ábra).

A közvetlen, nyílt kommunikáció tehát lehetővé teszi az információ, valamint a tudás megosztását. A kommunikációs szituációk egyik problémája azonban a bizalom hiánya. Ez a kapcsolat fordítva is fennáll: a bizalom létrejöttének alapfeltétele a szervezeti tagok nyílt, becsületes kommunikációja. A bizalom és a kommunikáció tehát kölcsönösen egymásra ható tényezők, ok és okozat állandóan szerepet cserélnek. Mivel a tudásmenedzsmentnek az a feladata, hogy a szervezet ismereteit átláthatóvá tegye, azaz a munkatársak osszák meg egymással tudásukat, a szervezeti tagok nem őrizhetik féltékenyen ismereteiket.

\section{6. ábra. Befolyásolja-e a munkatársába vetett bizalom, hogy mit és hogyan kommunikál vele szakmai kérdésekben?}

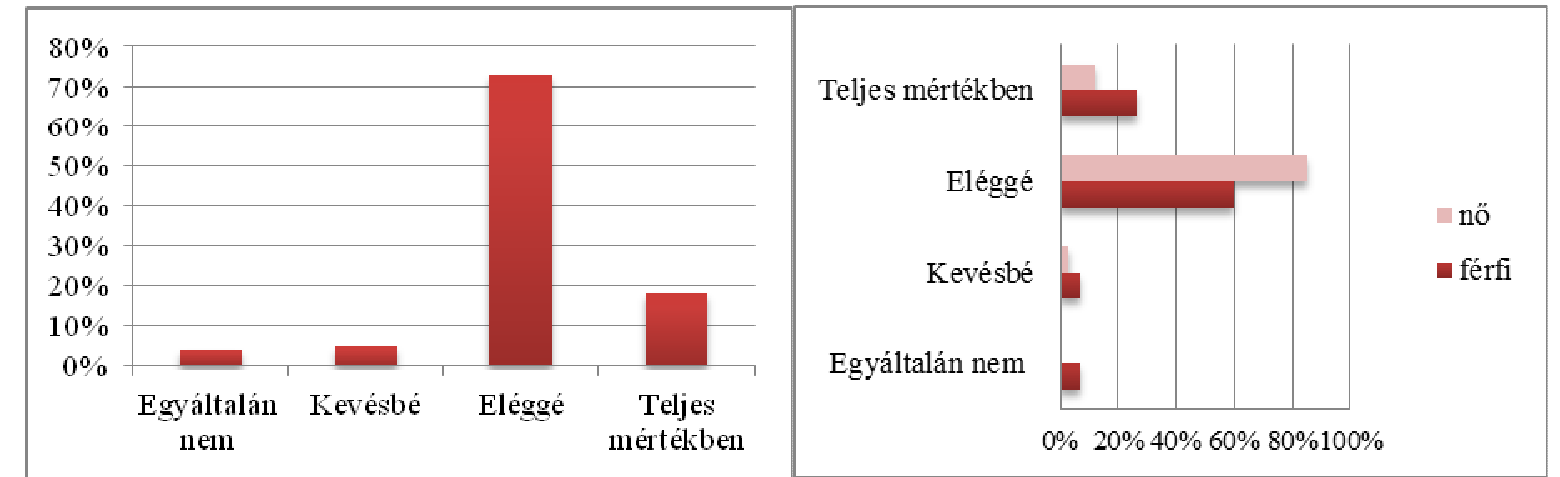

Saját szerkesztés

A bizalom szerepét a kommunikációban a megkérdezettek is igen fontosnak tartották. A férfivezetők azonban ebben a tekintetben szélsőségesebbek. Egynegyedük 100\%-os bizalmi 
szintet tart szükségesnek, míg akadnak közülük néhányan, akik egyáltalán nem tartják fontosnak a bizalom meglétét a szakmai kérdések megvitatásánál (6. ábra).

\section{Együttmüködés}

Az együttmüködés a tervek, információk és erőforrások megosztását jelenti, és megfelelő egyensúlyt biztosít a feladatok megoldása és a személyes kapcsolatok ápolása között. A tudásmenedzsmenttel foglalkozó kutatók azt vallják, hogy az „osszuk meg a legjobb gyakorlatot" elv sikere elsősorban a vezetői kultúrától függ, mert ha ök ezen értékek alapján müködnek, a szemlélet a szervezet alsóbb szintjeire is előbb-utóbb elkezd terjedni. Nem elhanyagolható kérdés tehát, hogyan értékeli egy szervezet vezetősége e helyzeteket, és ez által mennyi tudást tudnak kinyerni és felhasználni, illetve átadni a munkatársak tudásából.

A kérdőívekben az „egyáltalán nem” és a „néha” rubrikák üresen maradtak. Ez tény már önmagában is pozitív eredménynek számít. Néhány kutatás (mint például egyes játékelméleti kutatások) arról számol be, hogy a nők általában versengőbbek és kevésbé hajlandók együttmüködésre. A mostani eredmények ezt nem erősítik meg. A két nem között differencia az együttműködés területén csupán abban tér el, hogy milyen mértékűnek észlelik az általuk megosztott információ-, tudásátadást: gyakorinak vagy álladónak (7. ábra).

\section{7. ábra. Mennyiben osztják meg egymás között a munkával kapcsolatos információkat, terveket, erőforrásokat?}

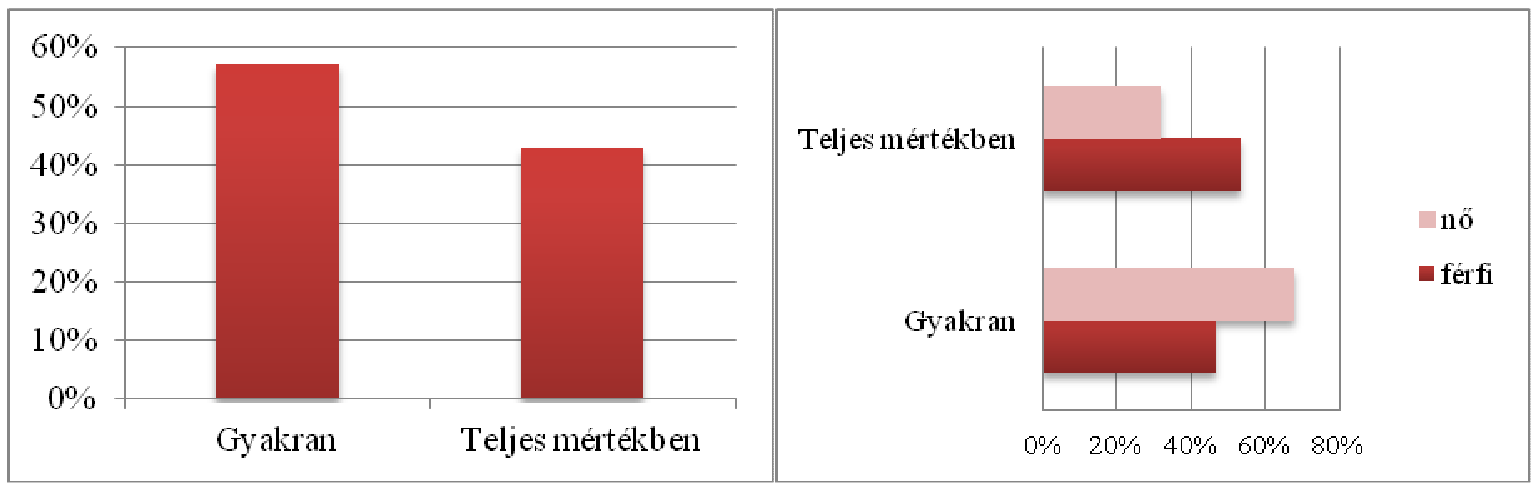

Saját szerkesztés

Az eredményes emberi együttmüködés minden területén nagy jelentősége van az emberek egymás közötti kapcsolatának, a munkához és a munkahelyhez való viszonyulásának. A kapcsolatépítés képessége az egyént alkalmassá teszi kiterjedt kapcsolati háló létrehozására. E képességgel bíró emberek jól ápolják a szervezeten belüli kapcsolataikat, sőt időnként szívesen létesítenek a szakmai kapcsolaton felül baráti kapcsolatot. Az ilyen erős vonzással 
bíró szervezeti tagok segítik a kommunikációt, a problémák megoldását, az együttmüködést egyaránt.

A kérdőívet kitöltő KKV-vezetők igen jónak ítélik meg kapcsolatukat munkatársaikkal. Csupán $10 \%$ az, akik nem tartják megfelelőnek azt. A nemek között ezen a területen nincs szinifikáns különbség (8. ábra).

A próbakérdöívben felsorolt 80 készség és képesség körét a tesztelés eredményének tükrében szűkítettük és a végleges kérdőívben már csak a 20 leggyakrabban említett kompetenciára kérdeztünk rá. ${ }^{4}$

A kompetenciák fontosságát egyrészt az jelzi, hogy hányan jelölték meg, másrészt az, hogy milyen fontosnak tartják. A két szempontot vizsgálva hasonló sorrendet kapunk. (9. ábra).

\section{8. ábra. Milyennek ítéli meg kapcsolatát a munkatársaival?}

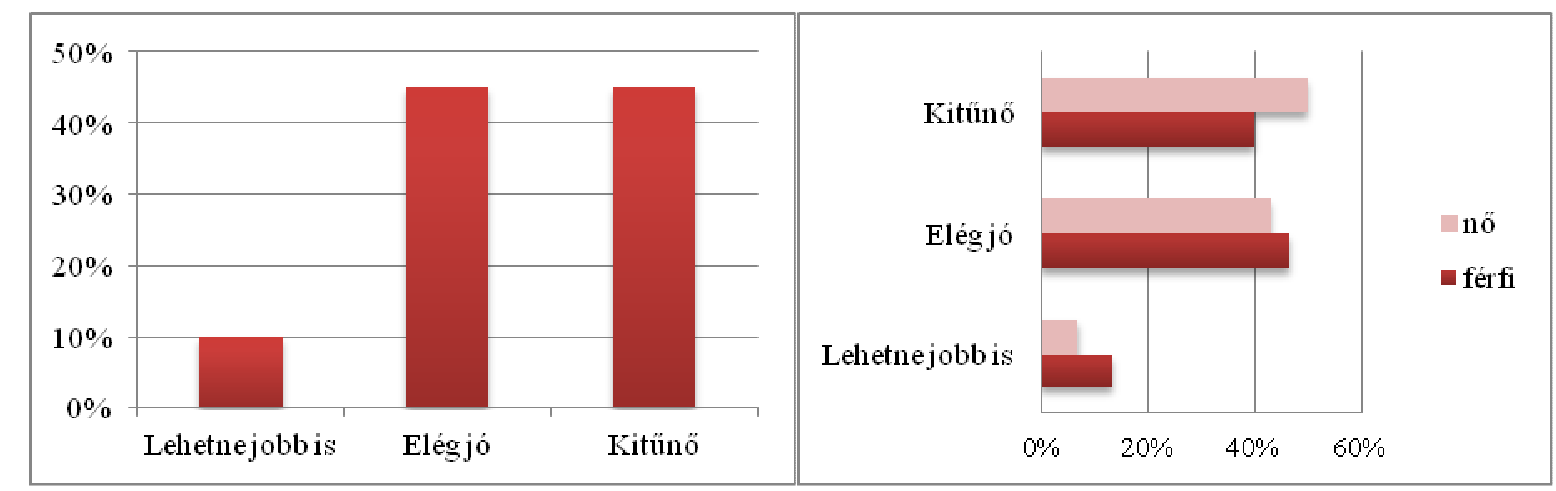

Saját szerkesztés

\footnotetext{
${ }^{4}$ Ezek a következők: megbízhatóság; probléma-megoldási készség; szaktudás alkalmazása a gyakorlatban; pontos, precíz munkavégzés; önállóság; kommunikációs képesség; együttmüködés; munkabírás, terhelhetőség; fejlödőképesség, önfejlesztés; kreativitás; tanulási, fejlődési képesség; kapcsolatépítés képessége; teljesítmény-, ill. eredményorientáltság; szervezési készség; stressztürő-képesség; elemzőkészség, analitikus szemlélet; kezdeményezőkészség; rugalmasság; motiválási képesség; munka iránti alázat, intenzív munkavégzés. A felsoroltakon kívül a megkérdezettek fontosnak tartották a nyelvtudást, valamint a számítógépes ismeretet, ezért ezeket is bevontuk a követelmények közé.
} 


\section{9. ábra. A megkérdezettek megoszlása a leendő munkavállalókkal szembeni elvárásaik szerint}

\begin{tabular}{|c|c|c|c|c|}
\hline EQ/IQ & $\begin{array}{l}\text { Képességek, } \\
\text { készségek }\end{array}$ & Mean & $\mathbf{N}$ & $\%$ \\
\hline \multirow[t]{4}{*}{ EQ } & Megbízhatóság & 5,7128 & 188 & 54,2 \\
\hline & $\begin{array}{l}\text { Pontos, precíz } \\
\text { munkavégzés }\end{array}$ & 5,6569 & 137 & 39,5 \\
\hline & $\begin{array}{c}\text { Szaktudás } \\
\text { alkalmazása a } \\
\text { gyakorlatban }\end{array}$ & 5,6194 & 134 & 38,6 \\
\hline & $\begin{array}{l}\text { Terhelhetőség, } \\
\text { munkabírás }\end{array}$ & 5,3684 & 95 & 27,4 \\
\hline \multirow[t]{3}{*}{ EQ } & $\begin{array}{l}\text { Kommunikációs } \\
\text { képesség }\end{array}$ & 5,3625 & 80 & 23,1 \\
\hline & Nyelvtudás & 5,3438 & 64 & 18,4 \\
\hline & $\begin{array}{l}\text { Problémamegoldási } \\
\text { készség }\end{array}$ & 5,2743 & 113 & 32,6 \\
\hline EQ & Önfejlesztés & 5,1667 & 48 & 13,8 \\
\hline \multirow[t]{2}{*}{ EQ } & $\begin{array}{l}\text { Kapcsolattartás, - } \\
\text { építés képessége }\end{array}$ & 5,16 & 50 & 14,4 \\
\hline & $\begin{array}{l}\text { Számítógépes } \\
\text { ismeret }\end{array}$ & 5,1489 & 47 & 13,5 \\
\hline \multirow[t]{2}{*}{ EQ } & $\begin{array}{l}\text { Stressztürö } \\
\text { képesség }\end{array}$ & 5,0917 & 120 & 34,6 \\
\hline & Munka iránti alázat & 5,075 & 40 & 11,5 \\
\hline EQ & Önállóság & 5,0702 & 57 & 16,4 \\
\hline EQ & Szervezési készség & 5 & 27 & 7,8 \\
\hline EQ & Együttműködés & 4,9818 & 55 & 15,9 \\
\hline EQ & $\begin{array}{l}\text { Kezdeményező- } \\
\text { készség }\end{array}$ & 4,7826 & 23 & 6,6 \\
\hline EQ & $\begin{array}{l}\text { Motiválási } \\
\text { képesség }\end{array}$ & 4,6154 & 13 & 3,7 \\
\hline & $\begin{array}{c}\text { Analitikus } \\
\text { szemlélet, } \\
\text { elemzőkészség }\end{array}$ & 4,3182 & 22 & 6,3 \\
\hline
\end{tabular}

\begin{tabular}{|c|c|c|c|c|}
\hline EQ/IQ & $\begin{array}{l}\text { Képességek, } \\
\text { készségek }\end{array}$ & $\mathbf{N}$ & $\%$ & Mean \\
\hline \multirow[t]{3}{*}{ EQ } & Megbízhatóság & 188 & 54,2 & 5,7128 \\
\hline & $\begin{array}{l}\text { Pontos, precíz } \\
\text { munkavégzés }\end{array}$ & 137 & 39,5 & 5,6569 \\
\hline & $\begin{array}{c}\text { Szaktudás } \\
\text { alkalmazása a } \\
\text { gyakorlatban }\end{array}$ & 134 & 38,6 & 5,6194 \\
\hline \multirow[t]{3}{*}{ EQ } & $\begin{array}{l}\text { Stressztűrő } \\
\text { képesség }\end{array}$ & 120 & 34,6 & 5,0917 \\
\hline & $\begin{array}{c}\text { Problémamegoldási } \\
\text { készség }\end{array}$ & 113 & 32,6 & 5,2743 \\
\hline & $\begin{array}{l}\text { Terhelhetőség, } \\
\text { munkabírás }\end{array}$ & 95 & 27,4 & 5,3684 \\
\hline EQ & $\begin{array}{l}\text { Kommunikációs } \\
\text { képesség }\end{array}$ & 80 & 23,1 & 5,3625 \\
\hline \multirow[t]{2}{*}{ EQ } & Nyelvtudás & 64 & 18,4 & 5,3438 \\
\hline & Önállóság & 57 & 16,4 & 5,0702 \\
\hline EQ & Együttműködés & 55 & 15,9 & 4,9818 \\
\hline EQ & $\begin{array}{l}\text { Kapcsolattartás, - } \\
\text { építés képessége }\end{array}$ & 50 & 14,4 & 5,16 \\
\hline \multirow[t]{2}{*}{ EQ } & Önfejlesztés & 48 & 13,8 & 5,1667 \\
\hline & $\begin{array}{c}\text { Számítógépes } \\
\text { ismeret }\end{array}$ & 47 & 13,5 & 5,1489 \\
\hline EQ & Munka iránti alázat & 40 & 11,5 & 5,075 \\
\hline EQ & Szervezési készség & 27 & 7,8 & 5 \\
\hline \multirow[t]{2}{*}{ EQ } & $\begin{array}{l}\text { Kezdeményezö- } \\
\text { készség }\end{array}$ & 23 & 6,6 & 4,7826 \\
\hline & $\begin{array}{l}\text { Analitikus } \\
\text { szemlélet, } \\
\text { elemzőkészség }\end{array}$ & 22 & 6,3 & 4,3182 \\
\hline EQ & $\begin{array}{l}\text { Motiválási } \\
\text { képesség }\end{array}$ & 13 & 3,7 & 4,6154 \\
\hline
\end{tabular}

Forrás: saját szerkesztés

Mindkét szempont szerint a legfontosabb kompetencia a megbízhatóság, ugyanis azt a megkérdezettek 54\%-a tartotta elengedhetetlenül fontosnak (átlagosan 5,71 ponttal 
értékelve).A második helyen a pontosság áll (39,5\%, átlagosan 5,66 ponttal), a harmadik legfontosabb elvárás pedig a szaktudás alkalmazása a gyakorlatban $(38,6 \%, 5,62$ ponttal).

Ezt követi a stressztürő-képesség (34,6\%), majd a probléma-megoldási készség 32,6\%kal.

A munkaerővel szembeni legfontosabb elvárások között tehát szerepelnek EQ elemek: a vezetők a munkaerő kiválasztása során fontosnak tartják azokat, de választásuk során mégsem ezt preferálják (11-ből4, míg nem EQ elemeknél 7-ből 6 szerepel az első 10-ben)

\section{KÖVETKEZTETÉSEK}

Ha egy szervezetnél vezetési problémák vannak, a kutatók egyre többet foglalkoznak a vezetők érzelmi megnyilvánulásaival, mint egyéb kompetenciáival. (Az EQ előtérbe kerülése nem azt jelenti, hogy már nincs szükség a magas szintű elemző - képességre, logikus gondolkodásra, döntések következményeinek megítélésére). Ahol a vezető képes lelkesíteni, ott a szervezet tagjai teljesítményének emelkedésére lehet számítani. Azok, akik megtapasztalják, hogy különböző érzelmi reakcióikkal ugyanabban a helyzetben más és más hatást válthatnak ki, szívesen építenek erre a „fegyverre”. A kutatás is bizonyította, hogy az érzelmileg intelligens vezető ráhangolódik munkatársai érzelmeire, tisztában van saját érzéseivel, indulataival, kézben tudja tartani azokat, és így képes megérteni másokat is. Az elemzett EQ (befolyásolás, együttműködés, kapcsolatépítés, kommunikáció, bizalom) tényezők fontos szerepet játszanak a munkájukban. Érdekes eredményt hozott kutatásunk második feltevésének vizsgálati eredménye, miszerint a munkaerővel szembeni legfontosabb elvárások között dominánsan IQ elemek szerepelnek.

Úgy gondoljuk, hogy a vezetőknek fel kell ismerniük, hogy az intelligencia egyénfüggő. A saját és a munkatársak más-más képességekben erősek, de ezek fejlesztésében kiemelkedő szerepe van a vezetőnek. Például nem az együttműködési készség növelhető közvetlenül, hanem azok az értékek, amelyek együttműködővé teszik a munkatársakat. A vezetői példamutatásnak ebben van nagy szerepe.

\section{FELHASZNÁLT IRODALOM}

Boyatzis, R., Goleman, D., McKee, A. (2003). A természetes vezetö. Az érzelmi intelligencia hatalma. Vince Kiadó. 317 p.

Carroll, J. B. (1993). Human cognitive abilities: A survey offactor-analytic studies. Cambridge, England: University of Cambridge Press

Ceci, S. J. (1990). On intelligence more or less: A bioecological treatise on intellectual development. Englewood Cliffs, NJ: PrenticeHall 
Cherniss, C. (1999). The Business Case for Emotional Intelligence. Prepared for the Consortium for Research on Emotional Intelligence in Organizations.

http://doreenmcgunagle.com/files/EI_Case_Study.pdf

Druskat, V. U., Wolf, S. B. (2002). A csoportok érzelmi intelligenciájának fejlesztése. Harvard Businessmanager, 2002/2. pp. 15-24.

Dulewicz, V., Higgs, M (1998). Emotional Intelligence: Can it be measured reliably and validly using competency data? Journal of Competency, Autumn.

Fenyvesi, É. (2010). Game Theory and Knowledge Management. Development and Finance. Quarterly Hungarian Economic Review. Published by the Strategic Advisory Board of the Hungarian Development Bank. 01/2010. pp. 31-39. ISSN 1589-3820

Gardner, H. (1983). Frames of mind: The theory of multiple intelligence. \$eG York: Basic Books

Goleman, D. (1997). Érzelmi intelligencia. HÁTTÉR Könyvkiadó. 454 p.

Gyarmathy, É. (2002). IQ és tehetség. (IQ and giftedness) Pszichológiai Szemle Könyvtára 5.Akadémiai Kiadó, Budapest. 127-154. oldalak

Heifetz, R., Grashow, A., Linsky, M. (2009). Vezetés (tartós) válság idején. HBR, 2009. november, pp. 20-22

Hermstein, R. J., Murray, C. (1994). The bell curve: Intelligence and class structure in American life. New York: Free Press

Hunter, J. E. (1983). A causal analysis of cognitive ability, job knowledge, job performance, and supervisor ratings. In: Landy, E., Zedeck, S., Cleveland J. (Eds.), Performancemeasurementandtheory(pp. 257-266). Hillsdale, NJ: Erlbaum

Kajári, K., Somogyi, S. Podruzsik, Sz. (2007). A csoportokon belüli erőviszonyok vizsgálataMACTOR módszerrel. Erdei Ferenc IV. Tudományos Konferencia I kötet 978-963-7294-65-5 Kecskemét 503-506. oldalak

Kárpátiné Daróczi, J., Vágány, J. (2011). Vezetőnek nem születünk, hanem azzá válunk, avagy a KKV-vezetők önképzési szokásai. Erdei Ferenc VI. Tudományos Konferencia 2011. augusztus 25-26./Kecskemét: Kecskeméti Főiskola Kertészeti Főiskolai Kar 2011. december, ISBN 978-963-7294-98-3 Ö ISBN 978-615-5192-00-5 II. kötet, 329-333. oldalak

Kotler, P., Caslione J. A. (2011). Kaotika. Manager Kiadó, Budapest, 2011.

Kovács, T. (2010). A bizalom szerepe és helye az érzelmi intelligenciában. Periodica Oeconomica, III. ÉVF. 2010. november. 48-58. oldalak

Mérő, L. (2010). Az érzelmek logikája. Terricum Kiadó, 2010.

Neisser, U., Boodoo, G., Bouchard, T. J., Boykin, A. W., Brody, N., Ceci, S. J., Halpern, D. F., Loehlin, J. C., Perloff, R., Sternberg, R. J., Urbina, S. (1996). Intelligence: Knowns and unknowns. American Psychologist, 51 (2), pp. 77-101

Rhodes, David, Stelter, Daniel (2009). Ragadjuk meg a recesszió nyújtotta lehetöségeket! HBR 2009. július-augusztus 32-33. oldalak

Salovey, P., Mayer, J. D. (1990). Emotional intelligence. Imagination. Cognition, and Personality, 9, pp. 185-211

SBA Fact Sheet Hungary, (2012). http://ec.europa.eu/enterprise/policies/sme/facts-figuresanalysis/performance-review/files/countries-sheets/2012/hungary_en.pdf (Letöltés: 2013. március 1.)

Tomka J. (2012). A vállalatok jobbá tételének trendjei. XXIII. Vezérigazgató találkozó, Tokaj-Hegyalja, 2012. április 18-20.

http://www.google.hu/url?sa=t\&rct=j\&q=\&esrc=s\&source=web\&cd=2\&ved=0CDUQFjAB\& url=http $\% 3 \mathrm{~A} \% 2 \mathrm{~F} \% 2 \mathrm{Fcebc} . \mathrm{hu} \% 2 \mathrm{Fppt} \% 2 \mathrm{Fxxiii}$ _ceo\%2Ftomka-

janos.pptx\&ei=7gQzUfelKYW2hAe0uYGoAw\&usg=AFQjCNE_mCAv0teBVkDyzRj 
nms-PbUopXQ\&sig2=VbJDOKdE7GdHr_cjDXTVaw\&bvm=bv.43148975,d.ZWU (Letöltve: 2013. március 3.)

Wimmer, Á., Zoltayné Paprika, Z. (2006). A vezetés és a döntéshozatal szerepének elemzése az üzleti szféra szempontjából. (Projektzáró-tanulmány) Versenyképesség kutatás mühelytanulmány-sorozat 45. kötete, 2006. május, 46-48. oldalak

Zsoldos, B. (2009). Az intelligenciahányadosról (IQ) és az érzelmi intelligenciáról (EQ. Magyar Grafika. 2009. 3. szám. 109-110. oldalak 